\title{
Stock Buybacks: Good Or Bad For Investors?
}

RamMohan R. Yallapragada, Fayetteville State University, USA

\begin{abstract}
A recent news flash announced that Warren Buffet's Berkshire Hathaway would buy back $\$ 1.2$ billion worth of its own Class A stock. In recent times, such stock buybacks are happening in rapid succession among companies all over the world. There are many advantages to investors of a company when the company buys back its own stock, generally known as treasury stock. Stock buybacks result in higher earnings per share (EPS), theoretically resulting in higher stock prices. Companies also resort to stock buybacks when they happen to have excessive cash balance. Cash rich companies are generally considered attractive targets for takeover possibilities. During times such as the present ones when returns on cash money market accounts do not yield attractive returns, companies usually implement stock buyback policies, thus earning better returns on excess cash while at the same time avoiding takeover possibilities. There are also some hidden advantages to senior management resulting from stock buybacks because of higher prices for their substantial stock options. There are also some disadvantages to investors resulting from stock buybacks.
\end{abstract}

This paper presents some of the main reasons for stock buybacks, and the consequential advantages and disadvantages to investors and other stakeholders.

Keywords: Generally Accepted Accounting Principles (GAAP); Financial Accounting Standards Board (FASB); United States (US); International Accounting Standards Board (IASB); International Financial Reporting Standards (IFRS); Securities and Exchange Commission (SE); Outright Adoption; Convergence; Endorsement and Condorsement; Push Back

\section{INTRODUCTION}

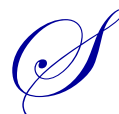

tock buybacks are booming again in a big way. Reimers and Singleton (2010) report that over the past decade, stock buybacks or purchases of treasury stock have become - and still continue to be - an increasingly important way of managing the balance sheet. Aggressive stock repurchases became a significant part of many corporations in their policies of their capital management structure. Many analysts attribute this phenomenon to weakening economy, falling prices of financial stocks and the sovereign debt crisis in Europe. Through the first half of 2011, Standard \& Poor's 500 Index (S \& P 500) companies repurchased about \$200 billion of their own stock (Friedman, Deblinger, \& Mantel, 2011). After a slowdown during the recession, the amount of stock buybacks by S \& P 500 companies has risen to about $\$ 500$ billion annual rate, almost double the rate of traditional cash dividends (Baldwin, 2012). Warren Buffett made the biggest news flash recently when Berkshire Hathaway announced that it would step up its stock buyback program (Arends, 2012). Berkshire made headlines when it started buying shares of its own stock for the first time in the company's history (Snider, 2011). Buffett decided to buy back up to 15 percent Berkshire's $\$ 150$ billion market cap (Lenzer, 2011). Berkshire Hathaway is not alone in this frenzy of stock buybacks.

Many of the brightest stars in the United States (US) business firmament are jumping on the band wagon of stock buybacks. Monsanto has recently authorized a three-year share repurchasing program totaling $\$ 1$ billion, effective July 1, 2012 (Valk, 2012). Apple is sitting on a mountain of close to $\$ 100$ billion in cash (Albenesius, 2012). Apple is going to buy back its own shares worth $\$ 10$ billion in its 2013 fiscal year (Moren, 2012). According to Valk (2012), chemical companies awash in cash have started returning more than 60 percent of their 
cash reserves to their shareholders in the shape of dividends and/or buybacks. For instance, in 2011, Ashland Company returned about 250 percent of their income from operations to shareholders, nearly all of it in stock buybacks. According to Savitz (2012), IBM board is authorizing a stock repurchase of nearly $\$ 11.7$ billion in the year 2013. In the first half of 2009, Exxon repurchased $\$ 13.1$ billion of its own shares, this after another buyback of $\$ 18.2$ billion worth of its own stock in the first half of 2008 (Dorsey, 2009). In 2008, Microsoft announced that it would buy back as much as $\$ 40$ billion of its own stock between 2008 and 2013. In the same year, Hewlett Packard announced that it would buy $\$ 8$ billion of its own shares (Dreyfuss, 2008). Fried (2007) states that even as far back as in 2007, 630 companies announced stock buybacks worth $\$ 369$ billion, the biggest of these being Proctor \& Gamble's $\$ 30$ billion buyback offer. In fact, from 2004 to 2008, companies flush with cash spent about $\$ 1.8$ trillion in stock buybacks (Cendrowski, 2011).

\section{TREASURY STOCK}

When a company buys its own stock, the purchased shares are known as "Treasury Stock." The dollar amount of the stock repurchased is debited to the Treasury Stock account and cash is credited. Since the stock purchased is from the company's own shares, the account of Treasury Stock cannot be considered as an asset/investment. It is a contra-stockholders equity account and is presented in the stockholders equity section of the balance sheet as a negative item (Horan, 2011). Under the Generally Accepted Accounting Principles (GAAP), two methods are available to account for treasury stock. The more frequently used method is known as the "Cost" method, under which treasury stock is recorded at cost and is shown at the bottom of the stockholders equity section as a deduction item. The other method is known as the "Par Value" method under which no treasury stock account is debited. The cost of the buyback shares is deducted from the "Paid-In-Capital" accounts. The shares purchased would be considered retired. If the company pays more than the original issue price of the repurchased shares, the excess amount is deducted from "Retained Earnings." Under both methods, total stockholders' equity is reduced by the amount of the stock buyback (Horan, 2011).

\section{WHY STOCK BUYBACKS?}

Evidently, many US companies are buying back a whole lot of their own stock now more than ever before. What are some of the main reasons for this phenomenon? Many companies state in their annual reports that they plan to repurchase their stock in order to meet their bonus and stock option plan targets (Lamba \& Miranda, 2010). However, as Reimers and Singleton (2010) report, many of these companies buy back much more than they need to meet their current and/or future stock options targets. Another reason for stock buybacks involves companies' efforts to maintain a desirable capital structure. Many finance experts believe that there exists an optimal capital structure, a correct mix of debt and equity financing that is most conducive for a company. So, companies use purchasing of treasury stock to adjust and maintain such optimum balance of debt and equity levels (Reimers \& Singleton, 2010).

However, one of the most salient reasons for the explosion of recent stock buybacks is that many of the companies are sitting on mountains of cash as they are going through a profit cycle that followed the 2001 financial bubble-burst. The piled-up cash balances are huge and one persistent question facing management is "what to do with this cash" (Sanford, 2005). If the same question were to be posed to an individual, the answer given by Bhirtruhari - a twelfth century philosopher-poet in India - was that one has to either spend it for oneself or donate the cash to charities. The only other alternative is that one will lose it in its entirety. However, for the companies, the alternative choices are different. In spite of several recent economic setbacks, such as sagging manufacturing numbers, debt-recycling crisis, and persistent high unemployment levels, corporate earnings keep marching on. However, few corporations are plowing their earnings back into their companies' operations or expansions. It is a typical case of catch-22. Companies will not be in a position to hire new workers until there is a rise in consumer demand, and consumers will not begin to spend more as long as the economy continues to stay bleak. (Editorial, Money Advisor, 2011).

Corporate management cannot sit idle on its excess cash for long. It will be forced to do something to put the excess cash to use that is profitable to the shareholders. Cash sitting idle or earning practically zero interest in money market accounts or treasury bills will reduce the return on equity which does not bode well for the 
company's standing in the market. Furthermore, cash rich companies also become very lucrative targets for hostile takeovers. If companies are not going to reinvest their cash in their companies, then they have three options: 1) Mergers and Acquisitions (M\&A), 2) Stock Buybacks, and 3) Pay Higher Dividends (Editorial, Money Advisor, 2011). Sanford (2005) states that in the past, the favorite choice of many companies with excess cash was to "merge and/or acquire" in order to keep extra cash within the company and try to boost their earnings. However, mergers and acquisitions do not always pan out in enhancing the interests of shareholders. The AOL/Time Warner merger of 2000 and the HP/Compaq merger of 2001 are but a few of the most frequently cited monumental examples of wellintentioned M \& A efforts gone awry (Sanford, 2005).

\section{ADVANTAGES OF STOCK BUYBACKS}

Since the early 1980s, besides dividends, repurchases of stock became a way that many US companies used to distribute cash to shareholders. Stock buybacks are no longer considered a novelty and they have become enduring and significant means of rewarding stockholders (Lamdin, 2001). The main advantages and the reason for stock buybacks are EPS, takeover threats, management signaling, and income tax advantage.

\section{Earnings per Share (EPS)}

The most common and also the most important accounting item of measurement for valuing a company is its Earnings per Share (EPS). EPS is computed by dividing the total earnings of a period with the outstanding number of shares of stock. For the same level of earnings, if the number of outstanding shares is reduced through stock buyback, the company's EPS is automatically increased without any corresponding increase in total earnings. A company with a higher EPS is viewed more favorably in the market than companies with lower EPS. Thus, increasing the EPS by way of stock buybacks would usually lead to higher stock prices (Walker, 2011). According to Horan (2011), the EPS is perhaps the most quoted accounting item in the annual reports of business entities, primarily because investors are very much interested in the effect of such report of EPS on the market prices of stock.

\section{Takeover Threats}

Companies sitting upon huge stockpiles of cash become lucrative targets for takeovers by other companies. Mohanty and Panda (2011) opine that companies use stock buybacks not only to increase the value of their shares in the market, but also to neutralize or eliminate any existing threats from predatory investors or companies who may be looking for a hostile takeover.

\section{Management Signaling}

Some companies also use buybacks for signaling to the market, in general, that their shares are undervalued, perhaps because their inside information is more positive than the public's perception of the company's strength. A large volume of stock buyback signals that the broad market is undervalued (Smith, 2006). In this context, pace (2005) states that when company buys back its own stock, it is an enormous vote of confidence by those who knows it best - the company's senior management.

\section{Income Tax Advantage}

Buybacks offer a tax advantage over dividends when companies wish to return part of their cash to shareholders. As Siegel (2006) states, when shareholders receive cash dividends, these are treated as ordinary income and the receipts are taxed at the prevailing personal income tax rate in the same year they are received. However, when companies buy back their own shares, any capital gains created for the shareholders are not taxed until the gains are realized; also, capital gains are taxed at a much lower rate. 


\section{DISADVANTAGES OF STOCK BUYBACKS}

\section{Manipulation of EPS}

EPS is the most important accounting number used by analysts to rate stocks of companies. Companies often manipulate the timing of the announcement of stock buybacks to arrive at an EPS number much higher than that forecast by stock analysts. This increase in the EPS is achieved without any corresponding increase in total earnings. Therefore, investors need to be very wary of buyback announcements just before earnings are reported.

\section{Implementation of Buyback Announcements}

A buyback announcement is usually followed by an increase in stock prices, but this increase could sometimes be temporary only. Furthermore, some announcement of stock buybacks would be implemented only partially and sometimes not at all. As La Monica (2005) states, there is no law that says any stock buyback announcement should be followed through.

\section{Management Compensation Contracts}

Senior management of companies endowed with generous stock options have a strong incentive toward announcing stock buybacks so that they can boost stock prices up before they start cashing in on their stock options. Furthermore, board compensation committees of many companies frequently link compensation packages for senior management to a target EPS. According to a very disturbing anecdote, a chief financial officer of a company was heard saying that all he had to do now to hit his target EPS was to figure out how many shares to buy back (Sanford, 2005). Sometimes managers tend to pad their own pockets through ill-timed buybacks. According to Fried (2012), there is ample evidence that insiders use private information to have companies secretly sell their own shares at prices favorable to them. The volume of such insider trading in some cases amounts to tens or hundreds of billions of dollars per year.

\section{CONCLUSION}

Over the past decade, stock buybacks or buying treasury stock by US companies has become an important method of managing their balance sheets. Stock buybacks reduce the number of outstanding shares, thereby increasing the EPS, shareholder value, leaning toward increasing stock prices. Buybacks are also used to distribute excess cash conveniently to stockholders. Buybacks are also used to avoid threats of possible hostile takeovers. However, not all buyback announcements are implemented since companies are not legally required to follow through on their announcements. Sometimes the increase in stock prices following a buyback announcement could be only temporary. Furthermore, senior managers tend to manipulate their EPS numbers through stock buyback announcements in order to meet their target EPS to receive a certain level of promised compensations linked to EPS. Investors need to be wary of buyback announcements to make sure that the stock buybacks do really bring about a long-standing improvement in shareholder value before they make any investment decisions based on the stock buyback announcements.

\section{AUTHOR INFORMATION}

RamMohan R. Yallapragada is a Professor of Accounting at Fayetteville State University. He obtained his PhD degree in Accounting from the University of Houston. He holds a CPA certificate from the State of Louisiana. His research areas include cost accounting in healthcare, accounting irregularities in Fannie Mae, impact of SarbanesOxley Act of 2002 on American corporations the effect of unprecedented growth in the economies of India and China on global trade, and the impact of adoption of IFRS in the United States.

\section{REFERENCES}

1. Albanesius, C. (2012). Apple uses part of cash hoard for dividends and share repurchases. PC Magazine, March 2012, 1. 
2. Arends, B. (2012). How to tell when a stock buyback is good for investors. Wall Street Journal, December 22-23, 2012, B7.

3. Baldwin, W. (2012). Cashing in on stealth dividends. Forbes, 189(1), 44-46.

4. Cendrowski, S. (2011). We buy high and sell low. Fortune, 164(2), 37-39.

5. Doesey, P. (2009). Using buybacks to help pick stocks. Money, 38(11), 59.

6. Dreyfuss, J. (2008). TechSpin: Microsoft and HP buyback shares. Red Herring, September 22, $2008,10$.

7. Editorial, Money Advisor (2011). Dividends or stock buybacks? Consumer Reports Money Advisor, 8(11), 8-9.

8. $\quad$ Fried, D. (2007). Buying into stock buybacks. Kiplinger's Personal Finance, 61(12), 20.

9. Fried, J. M. (2013). Insider trading via the corporation. (Harvard Law and Economics Discussion Paper No. 743) February 18, 2013.

10. Friedman, R. H., Deblinger, J. H., \& Mantel, K. S. (2011). Navigating public company equity buybacks. Insights: The Corporate \& Securities Law Advisor, 25(12), 2-12.

11. Horan, M. (2011). Are buybacks increasing EPS? Canadian Business, 78(19), 90-91.

12. La Monica, P. R. (2005). Love, but verify these buybacks. Money, 34(8), 6-8.

13. Lamba, A., \& Miranda, V. (2010). The role of executive stock options in on-market share buybacks. International Review of Finance, 10(3), 339-363.

14. Lamdin, D. J. (2001). Estimating the cost of equity for companies that repurchase: Theory and application. Engineering Economist, 46(1), 53-64.

15. Lenzer, R. (2011). Buffett's historic buyback is admission of weakness in markets. Forbes, September 26, 2011, 2.

16. Mohanty, M., \& Panda, S. (2011). A study on investors' reaction towards share buybacks in India. European Journal of Social Science, 46(1), 53-64.

17. Moren, D. (2012). Apple announces dividend, share buyback. Macworld, 29(6), 16.

18. Pace, N. W. (2005). Winners among companies that buy back stock. Kiplinger's Personal Finanxce, 59(3), 43.

19. Reimers, J. L., \& Singleton, C. J. (2010). Accounting meets strategy. Strategic Finance, 91(8), 46-51.

20. Sanford, J. (2005). Taking a little back. Canadian Business, 78(19), 90-91.

21. Savitz, E. (2012). IBM boosts buyback program by \$5 billion. Forbes.com, October, 30, $2012,16$.

22. Siegel, J. J. (2006). The economics of buybacks. Kiplinger's Personal Finance, 60(6), 52.

23. Smith, A. K. (2006). A bigger slice of the profits. Kiplinger's Personal Finance, 60(4), 20-22.

24. Snider, B. (2012). How to tell when a stock buyback is good for investors. Kiplinger's Personal Finance, 65(12), 17.

25. Valk, V. (2012). Report: Share buybacks, dividends on the rise. Chemical Week, 174(9), 11.

26. $\quad$----- (2012). Monsanto plans \$1 billion share buyback. Chemical Week, 174(16), 13.

27. Walker, C. (2011). Buybacks: Who wins? Money, 10(131), 82. 
NOTES 